\title{
fALE COM O PROFISSIONAL
}

Nesta sessão você pode entrar em contato com os profissionais disponíveis para tirar dúvidas, solicitar alguma informação ou simplesmente conversar.

Cláudia Maria Moura Pierre Socióloga

claudiampierre@gmail.com

Francinete Alves de Oliveira Giffoni

Médica - Psiquiatra

francinetealves@gmail.com
Gislene Farias de Oliveira

Psicóloga

Gislenefo@hotmail.com

Patrícia Nunes Fonseca

Psicóloga

patynfonseca@hotmail.com 